\title{
IRAQI WOMEN'S SITUATION AT THE END OF THE NINETEENTH CENTURY AND THE BEGINNING OF THE TWENTIETH CENTURY
}

\author{
Ahmed Al-Nasiri Abedalrazak \\ History Department \\ Wasit University \\ Al-Rabea District, Al Küt, Wasit, Iraq, 52001
}

\begin{abstract}
From a historical point of view, the Iraqi society is well known for its conservative social fabric, but that didn't necessarily mean that Iraqi women were shadowed over by that conservative atmosphere. Through its history Iraq has produced famous, courageous, and self dependent women, in different fields of life.

During Modern History Iraq was a part of the Ottoman Empire for about four centuries, with the decline of that Empire, the Iraqi society was affected either directly or indirectly, and the situation of women in Iraq wasn't getting any better, not to mention some of the local traditions that were designed to prevent women from taking their right role, even from a religious perspective, due to the tribal way of life that the Iraqi society was ruled by.

All the above and more were elements that slowed down women in the Iraqi society in having a wider, more diverse role, and resulted in the long lasting; acuminated an affection of these elements, the Iraqi society has lost its capacity to rebuild and flourish.

Keywords: women s' Rights, Iraqi Women, Women s’ Activities, Ottoman Era, Iraqi Society.
\end{abstract}

\section{Introduction}

During the late eighteenth century, and the beginning of the nineteenth century, Iraq gone through many of political and social ups and downs. As a part of the distinct Ottoman Empire, Iraq underwent a lot of conflicts, internally, and internationally, and due to that, thousands, and thousands of women lost their husbands, sons, or other family members, not to mention the lack of education, that most of the Iraqi society were facing, plus other social diseases, such as poverty, wrong traditional exercises, they were all factors resulted in reducing the role of women in the Iraqi society, during that time, and even after $[1,2]$.

\section{Aim of the research}

The research aims to shed the light on the situation, Iraqi Women were in, and the circumstances they were living through, and also, to point out the developments of women's role during the late nineteenth century, and the beginning of the twentieth century in Iraq.

\section{Materials and Methods}

Iraqi woman lived in so backward atmosphere during the Ottoman era. Even the social speech of the majority was very severe towards her. She had to go out of her house only twice, one time for her husband's house, and the second time for her grave. Women were treated as exotic creatures and they were shown as devils in popular proverbs [3]. Woman was oppressed by obsolete traditions which deprived her from her human value.

The mention of woman in public was against man social manners. Regarding marriage, woman had no opinion and she was forced to marry in backward social traditions. Usually the groom was her cousin (from the father) or another relative. Education of women was a social corruption. This situation remained till the end of the nineteenth century. The most radical thing a woman suffered from was social ban. In 1892 the Ottoman Mosul Governor tried to hold a census including men and women which made people furious. Consequently, a large number of them went to the Governor Headquarters to cancel that step. Eventually, he was ousted when the Mosul people's complaints reached the Ottoman capital [4].

The austere opinion towards women continued to prevail; but a girl school was opened in Iraq in the last year of the nineteenth century, i. e., 1899 [5]. This school was a turning point to 
start the Iraqi women renaissance to save them from ignorance and backwardness. However, there was a slowdown in this respect when the Ottoman governor Abdul-Wahab Pasha confronted a negative reaction when he called to grant women IDs. People of Baghdad, Mosul and Basra were furious at that. So he was obliged to withdraw that step [6]. That sole girl school was opposed by the clergymen who tried to base their stance on historical one and Numan Khairaldin Al-Alussi who published a book entitled "It is Right to Prevent Women from Writing" [7].

Suffering of Iraqi women continued; however, the year 1907 was a humble start for woman rising when the poet JameelSidqi al-Zahawi, who was one of the best Iraqi poets at that time, published a poem in which he criticized and attacked hijab saying that it was a reason for Moslems deterioration [8]. Al-Zahawi was following the Egyptian writer Qassim Ameen's steps. He was a pioneer of Modern Egyptian renaissance [9].

There was a clear political development after 1908 coup at the Ottoman capital; yet the Iraqi women reality improvement was very limited due to the control of conservatives who considered any movement on behalf of women progress as a challenge to them and beyond discussion.

Calling for educating women was one of the less signal issues because of the reservation of conservative forces in the country. Therefore, the Baghdadi "Al-Raqeeb" newspaper called for increasing the number of schools for girls to improve the situation of Iraqi families [10]. The Basra "Al-Eqadh" newspaper also called for establishing an organized school for girls in Basra city and ridiculed the female teacher's situation and described them as in need to learn [11].

Voices continued in calling for educating women because the illiteracy is the main reason of underdevelopment and not reaching the developed countries. The Basra "Al-Tahtheeb" newspaper published some essays of European intellectuals such as Jan Jack Russo which glorify the woman role as she represents the half of society [12]. "Al-Eqadh" newspaper described the education of Iraqi women as the main reason of the country development and construction [13]. The matter of educating women was enlarged and the conservative forces were attacked because of their narrow mind regarding the education of women. One of the writers describes the conservative forces' view regarding educating women as "the ignorance shame" [14]. "Sada Babel" newspaper's voice was very high when it mentioned that the country will not be progressed sine the women are uneducated and illiterate [15]. In order to lightening the Iraqi minds, the newspaper published the will of (Ottoman Governor Midhat Basha (1869 - 1872) which was calling for educating the woman because she is the nation spirit [16].

Journalism was the tribune which undertook the mission of improving the Iraqi woman's situation. Woman renaissance in Egypt and Levant had a big effect on journalism. It describes the uneducated woman as she killed children every year more than the number of killed people in the greatest wars [17].

The Iraqi journalism tried in the beginning of the twentieth century to attract the attention to the importance of women associations in women life in Iraq to improve the women social and educational situation. Arabic Language magazine called for following the Syrians step in establishing women associations. It wished that Iraq would have something like that [18]. "Sada Babel" newspaper exited the matter through admiring Ottoman women association which gathered money for supporting the Ottoman fleet [19].

Calling for women freedom was slow to avoid the collision with the conservative forces in the country. For example, in 1909, "Sada Babel" published three verse lines calling for removing the veil from women head without mentioning the poet's name; so it passed peacefully [20]. In the same year, the newsletter published a poem of Ma'rof Al-Rasafi which was more comprehensive in calling for women renaissance because the mothers are the standard of sons growing. Al-Rasafi denounced the traditions which discount women dignity and supported his opinion by depending on Islamic religion opinion in this issue saying that the Islamic religion imposes the education on the man and woman. The poet admired the Bedouin people who don't impose the veil on women. He reflects a lightening view about the role of woman in the Arabic heritage particularly in the wars and poetry writing but he didn't call for removing the veil [21].

Despite the truth that Al-Rasafi didn't call for removing the woman veil but his essay was criticized by the women freedom opposed forces because they think that the woman is not 
qualified for education [22]. Al-Raqeeb Journal mentioned that there isn't one woman among ten thousand can read and write in Baghdad because of the religious leaders who stand against the women education [23].

The sources mentioned that Al-Rusafi is the first who paid his attention to the women and supported her [24]. The poet didn't published his opinion in Arabic language but published a brochure in Turkish calling for the equality between woman and man and providing Iraqi woman with her political rights [25]. Al-Rusafi also called for dividing the work between man and woman for reaching typical family system [26].

Callings for protecting the women rights started to be high during the second decade of twentieth century. Arabic Language Magazines considered the woman as the base of social home and the woman adherence to the arts, sciences and traditions is very important for the actual construction and wanted civilization, as mentioned by that magazine [27]. "Al-Eloom" Magazine, which was issued in Baghdad, published a social novel titled (Baghdad Girl) which was considered as a big jump because it represented a challenge against the women freedom opposed forces [28].

The Iraqi journalism tried to talk about the woman role in the European societies and the women freedom there. "Al-Elim" magazine published some information about the British women migration to the British colonies for working and marriage [29]. Iraqi writers also published in the Lebanese journalism which was sold in Iraq about the woman freedom. One of them published in Lebanese "Al-Erfan" magazine an essay about the French woman role in the hard works and establishing the women associations which is no less than the man role. This was an important message to the conservative powers [30]. Another writer published an essay attaching the intolerance against women in the same magazine and criticized those who described her as unqualified for education [31].

Calling for educating women continued but in another way, such as home management and teaching Arabic grammar and other languages because it helps in the right upbringing. "Arab Language" Magazine praised the British woman describing her social development and rejected the voices which called for staying the woman in her social situation without any improvement [32]. The magazine also talked about the woman situation in Europe and USA and considered it as an important issue in the urbanization philosophy. It describes woman as a rival for man in medicine, engineering, industry, trading and law fields. The magazine said that the east deterioration is due to rejecting the girls educating because of the conservative forces. The magazine called the government and educated people in the country to follow the west steps in educating girls and also called for constructing schools for girls and arranging the family to prevent polygamy because the educated woman can match the man's need [33].

Two schools for girls were opened in Baghdad in 1909, one of them is primary and the second is an intermediate school. The total number of girls in the two schools was 200 students. This issue was a dangerous phenomenon as to the conservative forces, but it was a sign of optimism as to lightening forces [34].

Journalism used the importance of the woman freedom matter for consolidating the woman self-confidence and changing the view against the woman by referring to the role of woman in the modern world. The journalism continued in publishing about the European woman renaissance and her entrance to the work fields. "Europe women were rivals to men in the work fields" mentioned "Sada Babel" Journal [35]. Al-Raqeeb newspaper admired three female members in London Municipality Council who stayed sitting for 15 continuous hours to discuss the council works [36]. This was a clear message to Iraqi woman and to her conditions. "Al-Alem”Baghdad magazine published an essay talking about Europe woman renaissance and her participation in the political life such as election and conferences attendance and also her participation in the demonstrations. The magazine introduced the Polish-origin scientist (Maria Sclodovisca) (Madam Curie) the Professor at the French Sciences Schools and the woman of great discoveries, as an example [37]. The Egyptian "Al-Muqtaduf" magazine published two essays for an Iraqi writer about the European woman practicing medicine in different historical periods. It was a sign for an Ottoman order related to 1894 that gave the Ottoman woman the right of practicing medicine [38]. 
All the essays about the woman freedom in Iraqi and Arabian journalism were not positively received by the conservative forces. The conservative forces tried to stop such callings. For example, the tram Company which connect Baghdad center with Al-Kadhimiya city was criticized by conservative forces because of lifting the barriers which separated the women sitting places from the men sitting places [39]. The conservative forces prevented three women from entering (Qehwat Al-Shat) dance hall which was crowded by men despite the rejection of men [38] because they considered this behavior as a challenge to conservative forces.

An essay, published by the poet Jameel Sudqi Al-Zahawi in "Al-Muaid”Egyptian Journal, was a big change in the view towards Iraqi woman. The poet talked about a sensitive matter which is the head scarf and explained the effect of it on woman. He also talked about some matters in the Islamic religion, such as, divorce. He mentioned that Islam considers the woman as a half human being and her witness is considered to be a half and said that the veil weaken the sight of woman. When the magazine arrived in Baghdad, the conservative force described the poet as an atheist and called for judging him. The forces described him and his opinions as violent to the religion. This issue affected Ottoman authorities in Baghdad; therefore Nadhum Basha (Baghdad Governor) issued an order to isolate him from teaching in the College of Law [40].

As a result of that furious campaign against Al-Zahawi, he reversed his situation saying that it wasn't his opinion [41-43]. He was so frightened that he didn't leave his home for a week. The magazine "al-Muaid" tried to protect him by saying that the essay was not by his own handwriting [44].

Al-Zahawi topic also influenced Baghdad educated people, none of them dare to support him. But, after the campaign against Al-Zahawi being diminished, the support appeared when it was written that Al-Zahawi wanted the Iraqi woman to follow the western woman to have the same rights of men [45].

Al-Zahawi writing about the woman was secular and helped the renewing forces in Iraq to follow the reforming method. Al-Rusafa magazine talked about the importance of women, and the word (Umma) (Nation) is derived from (Al-Um) (the mother), because the nation can't be developed without woman development, and the society will be in permanent actual development by woman education, [46].

The period between (1908-1914) was representing a journalism attention to the matters of improving the woman situation despite that most of them was hesitant because of the heavy heritage on the Iraqi society. But the journalism put an important brick in the tower of renaissance of Iraqi woman in the period after the First World War and establishing of the Iraq State in 1921. In 1924, the number of schools for boys and girls reached 59 schools, which represented a real sign for the woman to be more involved in Activities of the Iraqi community, and be more productive during the following decades of the twentieth century [47].

\section{Result}

War circumstances, Iraq has faced during several periods of time, and the immature political experience, this country was and still facing, not to mention some wrong social practices, were all factors that participated in minimizing the women's role in their society

Due to all the above and more, the Iraqi society has unfortunately lost its capability to be more productive, especially when it comes to the necessity to be focused on rebuilding the country.

That has been said, women's successes equal brighter future of this country and any other country.

\section{Conclusion}

1. The women's position in Iraq during the late nineteenth and twentieth centuries was not socially advanced.

2. Iraqi women weren't doing any better in the political field.

3. War times have the huge negative effect on women in Iraq.

4. Wrong tribal traditions have also affected women in Iraq in the negative way.

5. Poverty and other social problems made things even worse for Iraqi women back then. 


\section{References}

[1] Lasky, M. P. Iraqi Women Under Siege. Available at: http://s3.amazonaws.com/codepink4peace. org/downloads/IraqiWomenReport.pdf

[2] Hassanpour, A. The (Re)production of Patriarchy in the Kurdish Language. Available at: http://fcis. oise.utoronto.ca/ mojabweb/publications/0001E478-80000012/0695C74C-001257DC.-1/hassanpour_11.pdf

[3] Longrigg, S. H. (1988). Modern Iraq from 1900 to 1950. Baghdad, 43.

[4] Fosil B. di (1968). Life in Iraq 1814-1914. Baghdad, 59-60.

[5] Al-Darbandi, A. A. (1968). Contemporary Iraqi Women. Vol. 1. Baghdad, 46.

[6] Al-Dirobi, I., Al-Baghdadiyon (1958). Their news and councils. Baghdad, 16.

[7] Al-Alussi, N. K. (1905). Injury in Preventing Women from Writing. Baghdad University, 719.

[8] Al-Moktatif, Magazine, Cairo (6 August 1907). Part. 8, P. 622.

[9] Arabic Language, Magazine (1 st August, 1907). Part10, Fifth Year, P. 582.

[10] Al-Raqeeb Newspaper (31 March, 1909). Baghdad, No. 7.

[11] Al-Eqadh Newspaper (27 October, 1909). Basra, Issue 20.

[12] Al-Tahtheeb,Newspaper (11 December, 1909). Basra, No. 28.

[13] Al-Eqadh, Newspaper (28 December, 1909). Issues 27.

[14] Al-Nebras, Magazine (13 November, 1909). Beirut, Part 9, P. 333-335.

[15] Sada Babel Newspaper (28 January 1910). Baghdad, No.24.

[16] Sada Babel (28 January, 1910). No. 9.

[17] Tahtheeb (18 December, 1909). No. 29.

[18] Language of the Arabs (July, 1913). Part 1, P. 53.

[19] Sada Babel (12 November 1911). No. 108.

[20] Sada Babel (31 December, 1909). No. 20.

[21] Al-Rasafi, D. M. (1986). Explanation and Commentary by Mustafa Ali. Part 2. Baghdad, 350-358.

[22] Al-Raqeeb (19 December, 1909). No. 74.

[23] Al-Raqeeb (19 December, 1909). No. 74.

[24] Al-Rehab Magazine (May, 1947). Baghdad, No. 10, P. 11.

[25] Al-Rasafi, M., Ara-Sanadah, A. Q. (1914). Is it possible to achieve equality between man and woman. Istanbul, 1333.

[26] Ma'rouf al-Rasafi, Arqlada, QadinAr-San'a, P. 28.

[27] Language of the Arabs (November, 1913). Part 5, P. 235.

[28] Al-Eloom Magazine (November 1910). Baghdad, part 1, P. 25.

[29] Al-Elim Magazine (1910). Baghdad, No. 5, P. 221.

[30] Al-Erfan Magazine (23 August 1914). Saida, Lebanon, Part 8, P. 207.

[31] Ezzeddin, Y., Al-Hindawi, K. (1974). His Life and the Poetry of his Poetry. Baghdad, 216.

[32] Arabic language (April 1913). Part 10, P. 445-451.

[33] Arabic Language (August 1914). Part 2, P. 64-70.

[34] Al-Raqeeb (19 December 1909). No. 74.

[35] Sada Babel (28 May, 1910). Issue 41.

[36] Al-Raqeeb (25 May, 1910). No. 118.

[37] Al-Elem (3 December, 1910). No. 9, P. 484.

[38] Al-Muktatif (1st November, 1912). Part 4, 1st October 1912, P. 329-336; Part 5, P. 446-449.

[39] Al-Raqeeb (22 April 1910). No.108.

[40] Al-Raqeeb (25 July 1912). No 140.

[41] Al-Zahawi Studies and Texts Prepared by Abdul Majid Al-Rushoudi (1966). Beirut, P. 112-117.

[42] Mustafa Nur al-Din Al-Wa'eez, Al-Rawd Al-Azhar in the Translations of Mr. Jaafar (1948). Mosul, P. 210.

[43] Al-Elem (3 December 1910). No. 9, P. 416.

[44] Al-Manar (2 December 1910). Part 11, P. 846.

[45] Tabaneh, B. A. (1947). Ma'rof al-Rasafi in a study of the poet of Iraq and his political and foreign environment. Cairo, 56.

[46] Al-Rasafa Magazine (1912). Baghdad, Part 1, P. 28-29.

[47] IRAQ Newspaper (17 February, 1925). No. 145. 